\title{
Araucnephia iberaensis n. sp., a Neotropical Black Fly with a Peculiar Distribution (Diptera-Simuliidae)
}

\author{
SCoscarón $/{ }^{+}$, CLCoscarón-Arias* \\ Facultad de Ciencias Naturales y Museo, 1900 La Plata, Argentina *Facultad de Ciencias Agrarias, Cinco Saltos, \\ Rio Negro, Argentina
}

Araucnephia Wygodzinsky \& Coscarón is a Neotropical black fly genus in which only one species from Central Chile is known. Another species has now been found in Corrientes province on the eastern side of the Iberá tropical swamps of Argentina, on the western border of the mountainous region of southern Brazil. This new species, A. iberaensis, is herein described and illustrated and information on its bionomics is recorded. It is an interesting species because previous to its discovery no black fly genus or subgenus from Central Chile region has been found in tropical areas, because these two regions are separated by the Monte and Pampas realms. Similarly, no Brazilian genus or subgenus has crossed the Andes mountains to Chile.

A comparison with other Neotropical, Nearctic, Ethiopian (Afrotropical) and Australian Prosimuliini (sensu Crosskey \& Howard) showed Araucnephia to be a valid taxon most closely related to Araucnephioides (sympatric in Chile). Araucnephia also shows great affinities with Lutzsimulium from Southeast Brazil and Argentina and Paracnephia from South Africa.

Key words: Neotropical black fly - new species - Prosimuliini - Argentina

The Neotropical black fly fauna is composed of 330 species within 11 genera (Crosskey \& Howard 1997). Nine of these genera are within the tribe Prosimuliini (sensu Crosskey) and are exclusively Neotropical. Seven are inhabitants of southern South America and are characterized by their high degree of endemism (Coscarón \& Coscarón-Arias 1995), as also are Simulium (Pternaspatha) and Simulium "blancasi group", both in the tribe Simuliini. Of the one genus of Prosimuliini and 11 subgenera of Simulium that occur on the oriental side of the Andes in tropical South America, none is found on the other side of the Andes; similarly, the black fly fauna from Chile and Argentina andean region are not found in the lowlands at the East of Argentina as if through biogeographic history, a strong barrier separates both regions. Until now the genus Araucnephia Wygodzinsky \& Coscarón 1973 was only represented by Araucnephia montana (Philippi), that occurs in Chile from Coquimbo to Curicó. This discovery of a second species for this genus from Northeast Argentina on the mountainous western border with Southeast Brazil is of interest, because until now no Chilean Simuliidae genera extend to the west of the Andean area.

The objective of this work is to describe a new species of black fly and discuss its systematic position with regard to closely related taxa.

\section{MATERIALS AND METHODS}

The material was obtained by the first author during three trips in June, August and November to the eastern border of Iberá Reserve in Corrientes province, Argentina. The Iberá Reserve is an area of wetlands known as the Esteros del Iberá and old Paraná river bed now occupied

\footnotetext{
+Correponding author. Fax: +54-221-425.7527. E-mail: sixtoco@museo.fcnym.unlp.edu.ar Received 21 March 2001 Accepted 24 July 2001
}

by lagoons and large tropical swamps. Larvae and pupae were collected in small creeks on the slopes of an undulating area near the provincial road number 41 , that runs along the border of the inundated area of the reserve. In the same area man biting females and females entering the vehicle were also collected between Ituzaingo and Galarza town. Immature stages and adults were preserved in alcohol and some adults were pinned. Material was dissected after treatment with sodium hydroxide solution and then mounted on slides in Canada balsam. Drawings were made with a camera lucida.

\section{Araucnephia iberaensis n.sp.}

Female: wing length 2.7-2.8 mm. Color generally blackish. Frons, clypeus, antenna, palpus and occiput black with grayish pollinosity. Scutum and metanotum blackish, humeral and pre-scutellar areas blackish brown with grayish pollinosity, scutellum blackish brown (Fig. 1A); wing veins light brown, legs brownish darkened on tarsites, halters light brown; abdomen blackish with grayish pollinosity, tergal plates velvety (brown in alcohol), darker than the rest of abdomen, pleura glabrous with grayish pollinosity; thoracic pilosity grayish. Frons relatively wide with abundant pilosity (Fig. 1B), frontal angle $=100^{\circ}$ : frontocular triangle a little wider than high (Fig. 1C). Clypeus about as long as wide. Antenna as Figure 1D. Palp with last article about twice length of penultimate, (Fig. 1E); sensory organ comparatively small, about $1 / 5$ of basal article length, with few tuberosities (Fig. 1F). Mandible denticulate on both sides with 14 (15)-26(27) teeth (Fig. 1G); maxilla with 25 teeth (Fig. 1H). Basal portion of cibarium smooth, with deep concavity rounded medially (Fig. 1I). Postoccipital cephalic area comparatively inflated (Fig. 1A). Thoracic hairs recumbent; wing with basal cell present; $C$ with spinules and setae; Sc with about 16-28 setae and 5-8 placoid setae. Basal sector of $\mathrm{R}$ with hairs arranged in 2-3 rows and presence of placoid setae; $\mathrm{R} 1$ with finer spinules than on $\mathrm{C}$ together with spines. Hairs on legs filiform with variable size. Calcipala present and pedisulcus absent (Figs $1 \mathrm{~J}-\mathrm{K})$; ratio length/width of basitarsus III $=8.5$. Claws with small, sub-triangular-shaped subbasal tooth (Figs 1L-M). 

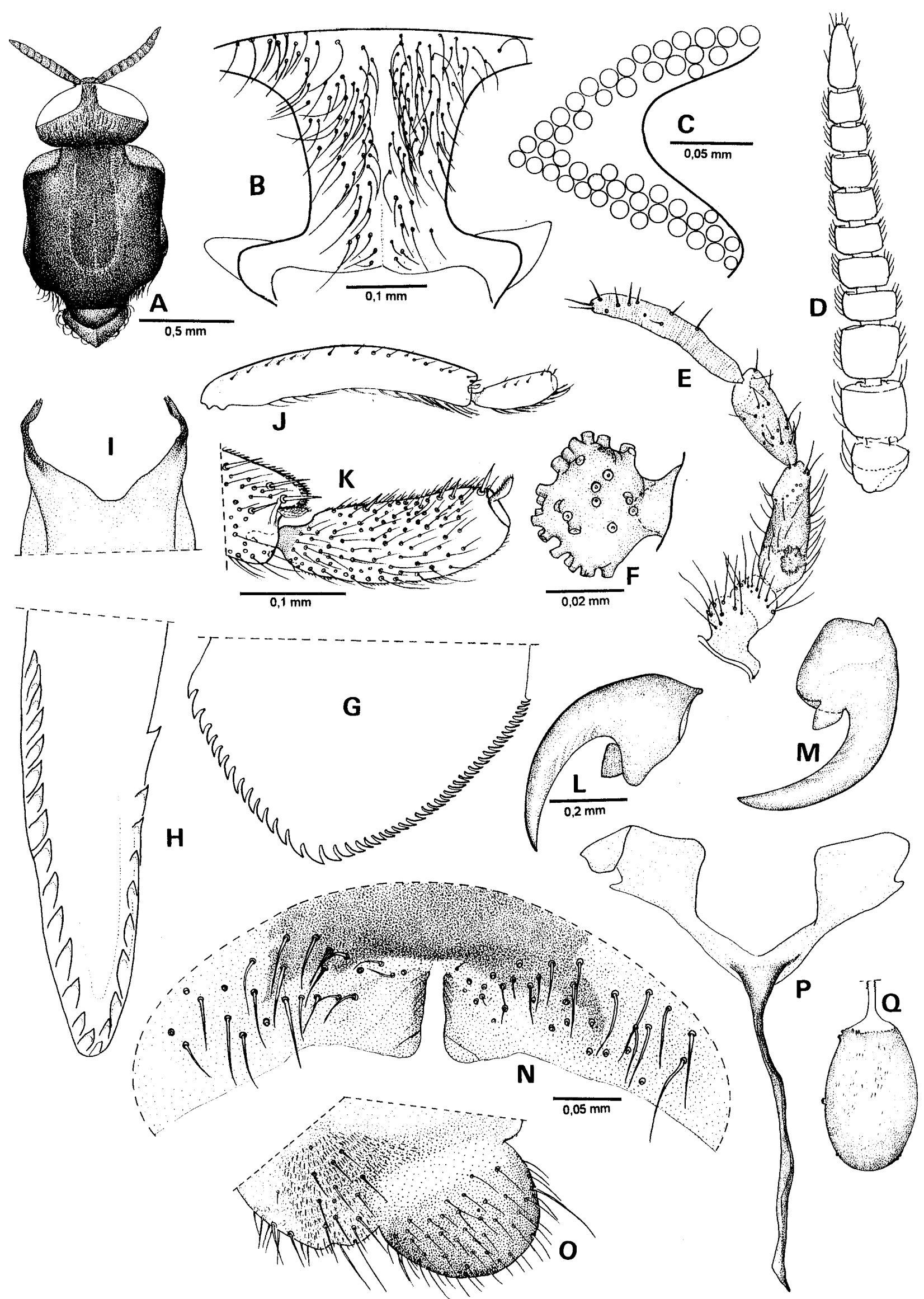

Fig. 1 A-Q, female - A: head and thorax on dorsal view; B: front; C: frontocular triangle; D: antenna; E: palpus; F: sensorial organ of palpus; G: portion dentate of mandible; H: portion dentate of maxilla; I: basal portion of cibarium; J: tarsite I and II; K: calcipala and tarsite II; LM: claw in different view; N: VIII sternite and gonapophysis; O: paraproct and cercus; P: genital fork; Q: spermatheca; (similar scale: B, $\mathrm{D}, \mathrm{E}, \mathrm{J} ; \mathrm{F}, \mathrm{G}, \mathrm{H} ; \mathrm{L}, \mathrm{M} ; \mathrm{N}, \mathrm{O}, \mathrm{P}, \mathrm{Q})$ 


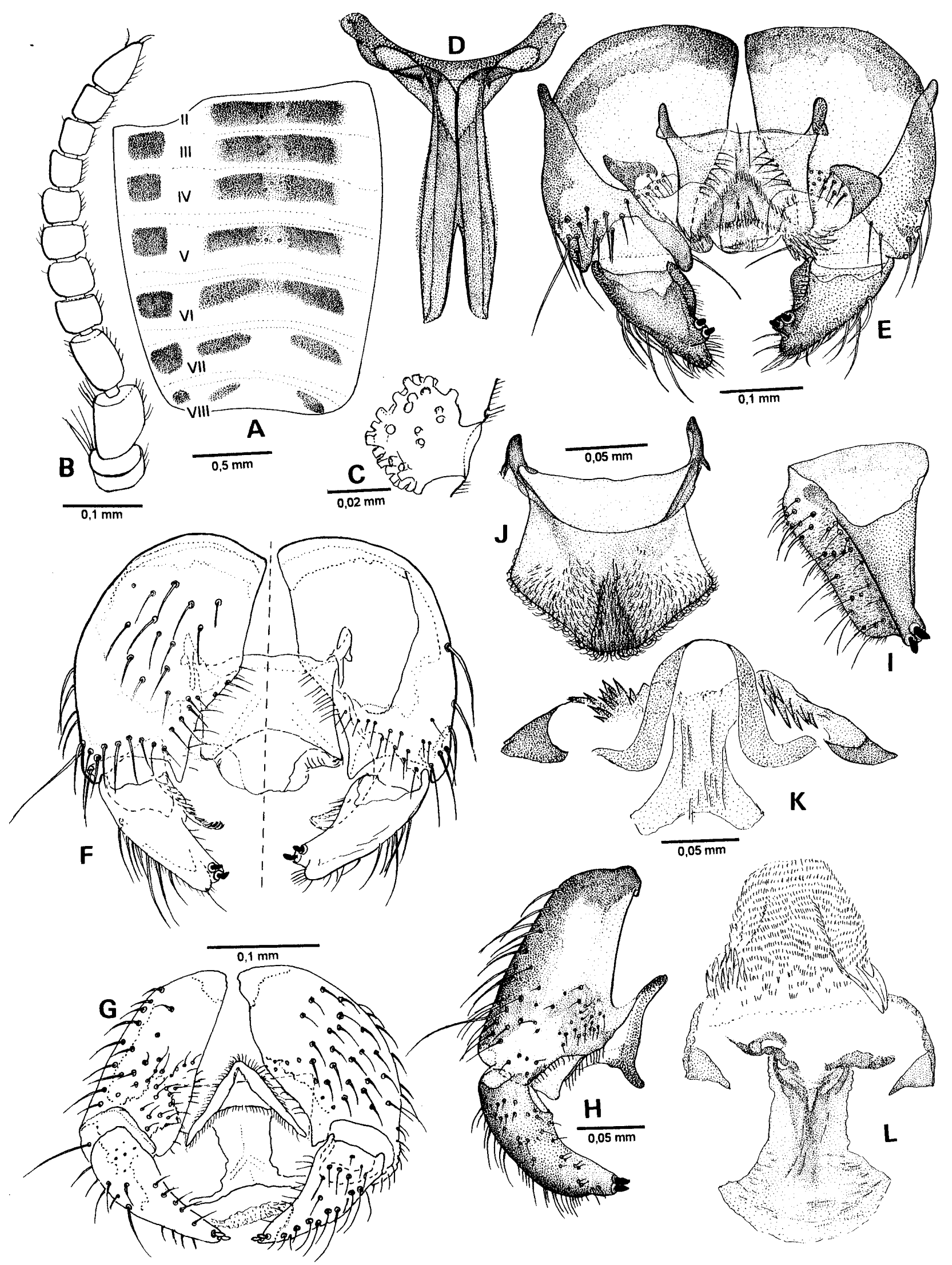

Fig. 2 A-L, male - A: abdomen sclerotized areas in slide view (right tergites, left sternites); B: antenna; C: sensorial organ of palpus; D: furcasternum; E-G: genitalia in different view; H: basistyle and dististyle in ventro-lateral view; I: dististyle internal view; J: ventral plate; $\mathrm{K}$ : endoparameres and median sclerite; L: aedeagus, endoparameres and median sclerite in another position; (similar scale: B, D; E, F; I, J, L) 
Eighth sternum mostly darkened with 21-24 trichomes, gonapophysis with 6-7 hairs, truncated distally slightly sclerotized on internal side, and with rounded internal angle (Fig. 1N). Cerci with rounded margin, paraproct short (Fig. 1O); genital fork with thin median branch and lateral branches expanded distally (Fig. 1P); spermatheca subovoidal with hyaline neck, showing some superficial tubercles (Fig. 1Q).

Male: wing length 2.6-2.7 mm. General coloration very similar to female, scutum brown, lighter on latero-posterior border, metanotum velvety black, legs lighter brown with posterior half of femur, tibia and tarsites blackish. Abdomen brownish, a longitudinal blackish stripe composed of subtrapezoidal, sclerotized tergal plates on segments II-V and 1+1 sublateral spots on segments VI-VIII; ventrally with subquadrate spots blackish on segments III-VIII (Fig. 2A). Antennal shape as Fig. 2B. Sensory vesicle of palp very small (Fig. 2C). Chaetotaxy of wing as female. Ratio length/width of basitarsus III = 4.4. Furcasternum expanded at sides of median branch (Fig. 2D). Dististyle shorter than basistyle, subconical, with two longitudinal crest and distally with a depression and two apical spurs (Figs 2E-I); ventral plate sub-pentagonal with small median crest (Fig. $2 \mathrm{~J})$; median sclerite robust in form of curved plate; endoparameres with large basal plate and abundant and very small denticles distally; aedeagus membranous with abundant microtrichiae (Figs 2K-L).

Pupa: cocoon length 3.6-4.2 mm; total pupa length 6-6.3 $\mathrm{mm}$, gill length 2-3 mm. Cocoon not compact, generally covering pupa up to base of gill, fine weave to extent that threads not evident thereby making pupa visible (Fig. $3 \mathrm{~A})$. Head of pupa and body light brown. Frontoclypeus and thorax with abundant platelets mostly verrucose, frontoclypeus with 1+1 frontal and facial trichomes, 2+2 epicraneal, lateral and genal trichomes, all hair-like some curved distally (Fig. 3B). Thorax with 6-8 stout and single trichomes on each side, four more robust on disk curved apically (Fig. 3C). Gill with 9 terminal branches and short basal trunk, showing 3 short primary branches carrying 2 secondary branches each, one of which is thinner and undivided and other thicker and bifurcated at short distance from base (Fig. 3D); surface of filaments pitted. Abdomen hard, sclerotized with numerous, small platelets, chaetotaxy as typical of genus, with strong terminal hooks and several loopped trichomes (Figs 3E-F).

Larva: maximum length 6.6-7.6 mm. Color light grayish brown. Head light brown with positive spots and very evident ornamentation, with darker area around ocular spot (Figs 4A-B); cephalic apotome spots blackish brown as follows: $1+1$ basal submedian transverse spots, one median longitudinal and $1+1(2+2)$ small in the middle and inferior third of head length (Fig. 4C). Cervical sclerites wide, fused with upper ends of postocciput. Hypostomium with three groups of teeth with median and corner teeth about same height and longer than other teeth; laterally with 5-6 serrations on each side (Fig. 4D); lateral setae of hypostomium very long in number $4-5$ on each side, disposed in one or two rows, on disc 2-3 setae. Gular cleft shallow with soft internal curve. Ratio hypostomium/ hypostomial bridge $=0.6$. Antennae about same length as stem of cephalic fan. Basal articles robust (Fig. 4E); ratio of articles I-III = 1:1,2-1,5:2,4-2,8. Cephalic fan with 48-54 rays; comb of rays composed of series of smaller teeth between two long teeth and half length of long teeth (Fig. 4F). Mandible with two outer teeth, one apical and three pre-apical, with third hard longer than others; internal teeth arranged in two rows with 11-13 teeth each; 8-12 marginal teeth, the first longest, two accessory teeth on the external side sometimes present anterior to first or at same level as median internal (Figs 4G-H). Palp elongated (Fig. 4I). Comb of pseudopod sclerite with 15-17 teeth and sclerite enlarged medially (Fig. 4J). Anal sclerite X shaped (Fig. 4K) with single trichomes and abundant scales with 4-8 branches (Fig. 4L). Anal ring with 64-66 rows of 14-16 hooks each. Anal gill with 3 long lobes undivided (Fig. 4M).

Material examined: ARGENTINA: Corrientes on provincial route number 41, between Federal Highway 12 crossing State Way 41 (S $27^{\circ} 40^{\prime} 49^{\prime \prime}$, W 56 $\left.28^{\circ} 27^{\prime \prime}\right)$ and Galarza town (S 28`06'03”, W 56 39' 51'), col. S. Coscarón (MLP), 1/2-06-00, man biting: 2 females (paratypes) on pick-up: 1 female (Holotype); creek $5 \mathrm{~km}$ South to Estancia San Antonio: 2 pupae, 4 larvae, (sympatric with Simulium perflavum Roubaud; same locality, 6-XI-00: 1 larva, (sympatric with $S$. minuanum Strieder and Coscarón and $S$. delponteianum Wygodzinsky) (S 2748'44”, W 56²4'49”), 6-XI-00: 1 pupa 6 larvae; creek $5 \mathrm{~km}$ South of Itacua: 4 pupae, 12 larvae (sympatric with $S$. subpallidum Lutz); creek $8 \mathrm{~km}$ North of Galarza: 2 pharate female and 1 pharate male on slides (paratypes), 8 pupae, 4 larvae (sympatric with S. minuanum); creek 2 km North of Galarza: 2 pupae, 2 larvae and 2 larvae in slides (sympatric with S. perflavum, S. subpallidum, S. pertinax Kollar, S. minuanum and $S$. (Inaequalium) sp. Same area 13-08-00. Second creek South of Highway 12 to Itacua: 1 pupa (sympatric with $S$. perflavum, S. minuanum and S. inaequale (Paterson \& Shannon); Fourth creek S. Highway 12: 1 female pinned (paratype) 2 pupae, 6 larvae (sympatric with $S$. inaequale and $S$. minuanum); creek $3 \mathrm{~km}$ South Itacua: 8 larvae (sympatric with $S$. minuanum and $S$. auripellitum Enderlein; creek between Itacua and Galarza: 1 pharate female and 2 pharate male (paratypes), 2 larvae on slides, 13 pupae and 9 larvae. Creek in front of park guard's house: 1 pharate male on slide (paratype), 3 larvae (sympatric with $S$. perflavum and $S$. minuanum). All material is deposited in Museo La Plata, Argentina.

Bionomics: A. iberaensis breeds in small creeks $0.5-3 \mathrm{~m}$ wide, and 0.1-0.5 m deep with crystalline water and strong but not torrential current speed. Larvae and pupae found on aquatic vegetation. Females are hematophagous and bite man. The bite produces a hard spot followed by an allergic reaction. This reaction is one of the worst suffered by the collector from a black fly bite.

Discussion: the new taxon is within the genus Araucnephia as originally defined by Wygodzinsky and Coscarón 1973. Characters to separate A. iberaensis from A. montana are as follows: A. montana has pupal gill with 14 branches, frontoclypeus and thorax without platelets, trichomes of thorax straight distally; in larva head dark brown and the dorsal dark spots not well defined; gular cleft deeper with ratio hypostomium/hypostomial bridge $=$ 1 , median tooth of hypostomium at same or beyond level of lateral teeth, antenna shorter than stem of cephalic fan, marginal serrations of mandible with 7-15 denticles and absence of large, anteriorly positioned accessory tooth, cephalic apotome sclerite with transverse maximum width some distance above of base, cephalic fan with about 24 rays showing comb teeth of rays of similar length and lateral sclerite of pseudopodium with about 56 teeth. Minor differences occur in larval antennal article length, and number of maxilla and mandible teeth. 
A comparative morphological analysis of Araucnephia (Wygodzinsky \& Coscarón 1973) revealed that this genus is most closely related to Araucnephioides and shows little affinity with other Neotropical Prosimuliini and some Nearctic genera. One taxon super- ficially treated in that revision was Paracnephia (Paracnephia) from the Ethiopian (Afrotropical) region, that we compare in more detail here (Table). Lutzsimulium is also included because it is now known to be sympatric with genera of the tribe Prosimuliini. These analyses dem-

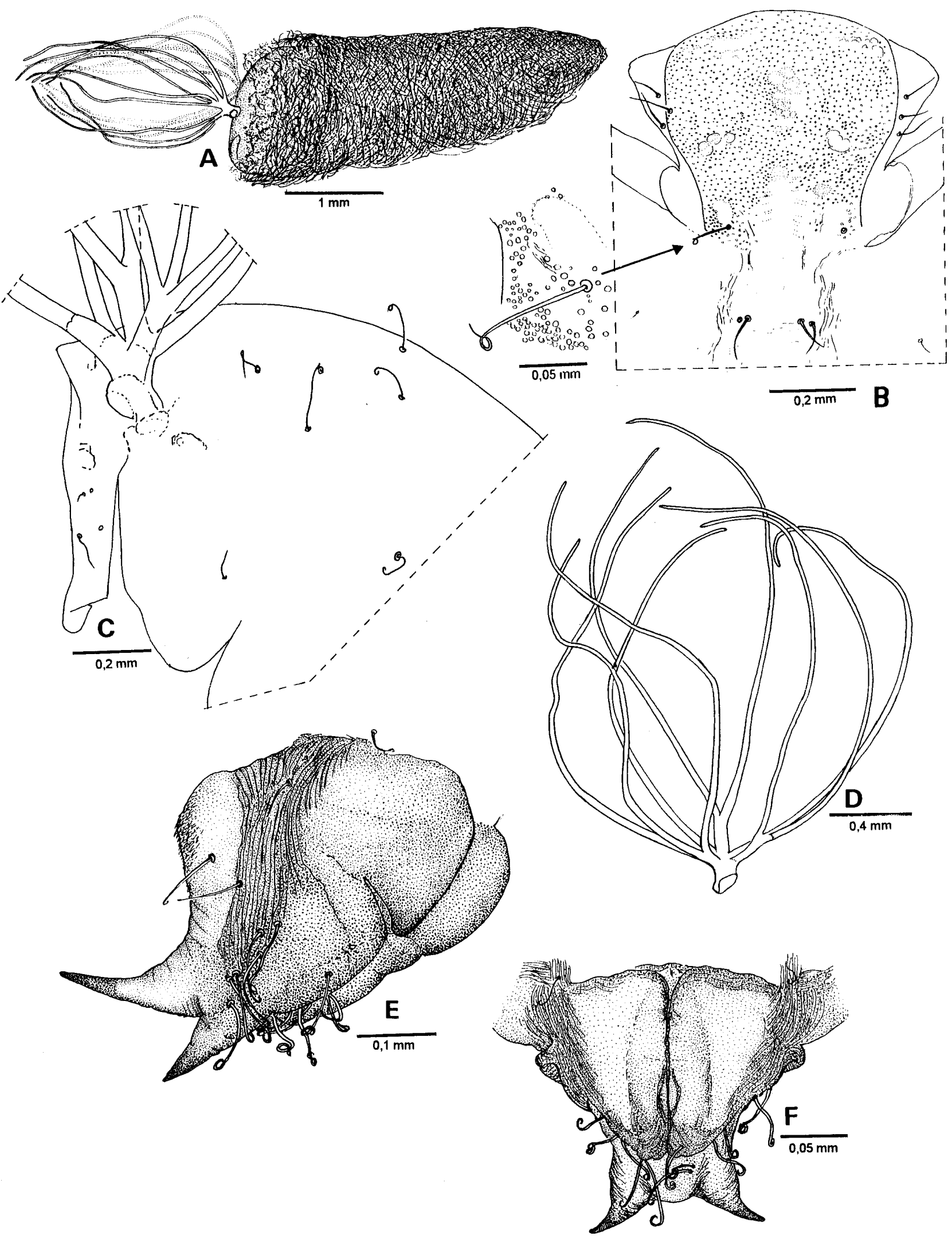

Fig. 3 A-F, pupa - A: general aspect; B: frontoclypeus; C: hairs of thorax disk; D: respiratory filaments; E-F: distal portion of abdomen in lateral and ventral view 


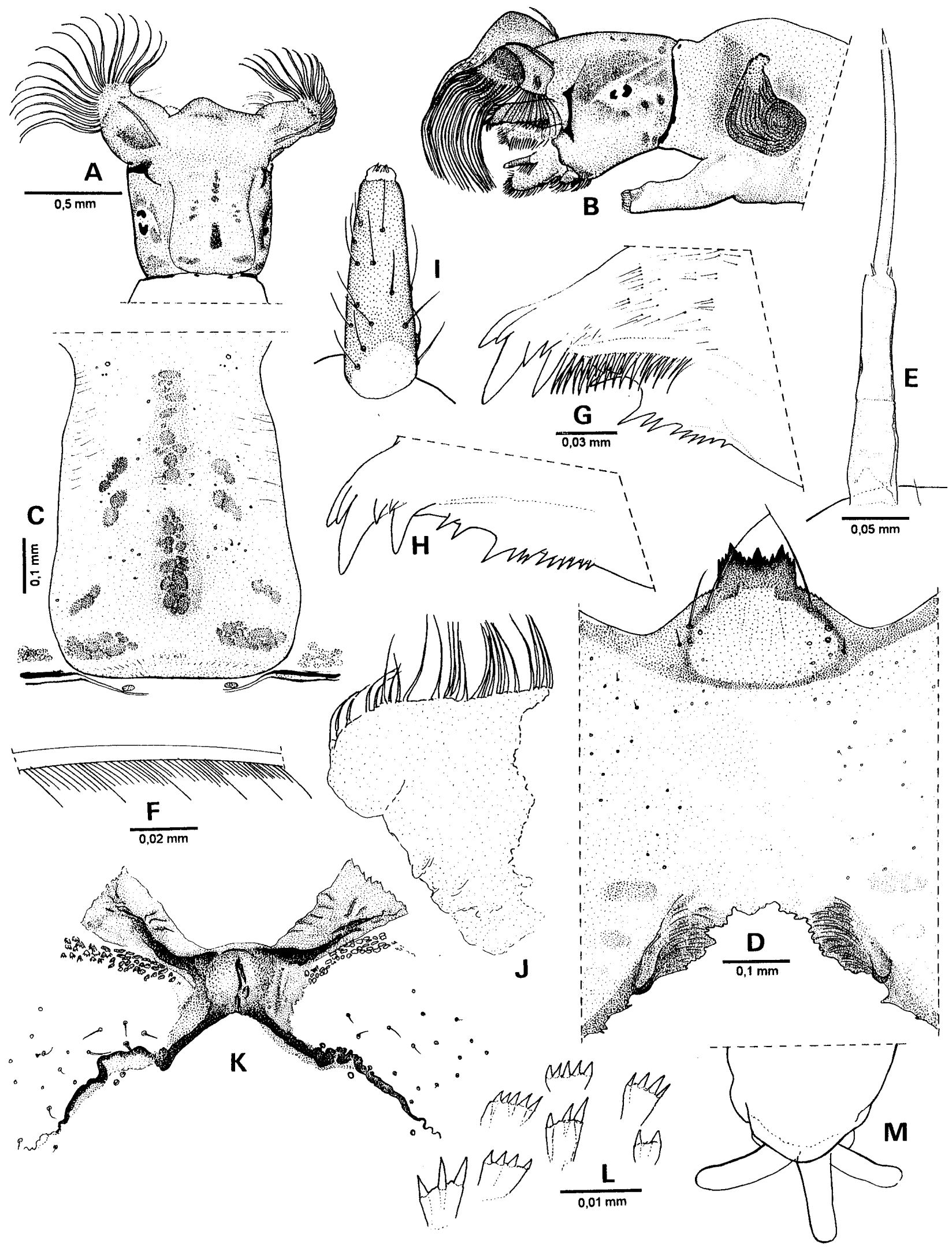

Fig. 4 A-M, larva - A-B: head in dorsal and lateral view respectively; C: cephalic apotome; D: ventral portion of head with hypostomium; E: antenna; F: portion of cephalic fan comb, showing different length teeth; G-H: apical portion of mandible (in $\mathrm{H}$ without internal teeth); I: palpus; J: pseudopod sclerite showing the comb teeth; K: anal sclerite; L: scales of anal sclerite; M: anal gill; (similar scale: A, B, M; C, $\mathrm{K} ; \mathrm{E}, \mathrm{I} ; \mathrm{G}, \mathrm{H}, \mathrm{J})$ 
TABLE

Morphological characters showing similarities and differences with genera Araucnephia, Araucnephioides, Lutzsimulium and Paracnephia (from South Africa)

\begin{tabular}{|c|c|c|c|c|}
\hline Characters & Araucnephia & Araucnephioides & Lutzsimulium & Paracnephia \\
\hline Scutum hairs & Recumbent & Recumbent+erect & Recumbent & Recumb-+erect \\
\hline Furcasternum median arm with conspicuous & Narrow & Wide medially & Wide all along & Wide medially \\
\hline lateral projections & & & & \\
\hline Projections of furcasternum transversal arm & - & - & + & + \\
\hline $\begin{array}{l}\text { Ratio of basal section of } \mathrm{R} \text { to length until wing distal } \\
\text { border below } 3.5\end{array}$ & + & + & + & $-($ over 4$)$ \\
\hline \multicolumn{5}{|l|}{ Female } \\
\hline Frons wide (frontal angle over $100^{\circ}$ ) & + & - (narrow) & - (narrow) & - (narrow) \\
\hline Emergence of subbasal claw tooth since base & + & + & Since claw body & + \\
\hline Subbasal claw tooth shape & Subtriangle & Hook-like & $\begin{array}{l}\text { Very small } \\
\text { subtriangle }\end{array}$ & Subovoidal \\
\hline Gonapophysis internal border & Subparallel & Subparallel & Subparallel & Convergent distally \\
\hline Insertion area of spermatheca with spermathecal duct & With tran & lucent area & Sclerotized u & intil duct base \\
\hline \multicolumn{5}{|l|}{ Male } \\
\hline Ventral plate apical shape slightly accuminated & + & Bilobate & Bilobate & + \\
\hline Endoparamere hooks short & + & + & Elongated & + \\
\hline Dististyle spur number & 2 & 2 & 2 & 5 \\
\hline Dististyle shorter than basistyle & + & + & + & -Similar length \\
\hline \multicolumn{5}{|l|}{ Pupa } \\
\hline Frontoclypeus frontal trichomes hooked distally & + & Straight & + & Straight \\
\hline Number of gill main branches up to 4 & + & + & $5-6$ & + \\
\hline Abdomen terminal setae hooked & + & + & + & - (some bifurcated) \\
\hline \multicolumn{5}{|l|}{ Larva } \\
\hline Cephalic apotome with $1+1$ basal spots & + & + & -+ & - \\
\hline Antennal basal article shorter than second & + & + & Similar length & + \\
\hline Third antennal article shorter than second & $+(=)$ & - & - & + \\
\hline Antenna shorter than stem of cephalic fan & + & - & - & + \\
\hline Mandibular serrulations in number 8-20 & + & + & $-(1-2)$ & + \\
\hline Mandible apical tooth very developed & - & - & - & + \\
\hline Hypostomium with large teeth arranged in three groups & + & + & - & + \\
\hline Postgenal bridge longer than height of hypostomium & + & + & Shorter (or similar) & + \\
\hline Larval neck sclerites fused to upper ends of postocciput & + & - & -+ & + \\
\hline Number of anal hooks rows & $80-100$ & $60-67$ & $75-110$ & About 150 \\
\hline
\end{tabular}

onstrate several characters in common, suggesting that these genera plus Araucnephioides probably have a Gondwanian common ancestor.

\section{ACKNOWLEDGEMENTS}

To Dr Blanca Alvarez de Avanza (Faculty of Exact and Natural Sciences of the North East University) for logistical support for fieldwork through the Iberá Project. To Dr AJ Shelley from the British Museum of Natural History for the suggestions to the text and the loan of Paracnephia species from South Africa. To Nélida R Caligaris for the illustrations.

\section{REFERENCES}

Coscarón S, Coscarón-Arias CL 1995. Distribution of Neotropical Simuliidae (Insecta-Diptera) and its areas of endemism. Rev Acad Colomb Cienc 19: 717-732.

Crosskey RW, Howard TM 1997. A New Taxonomic and Geographical Inventory of World Blackflies (Diptera: Simuliidae), The Natural History Museum, London, $144 \mathrm{pp}$.

Wygodzinsky P, Coscarón S 1973. A review of Mesoamerican and South American black flies of the tribe Prosimuliini (Simuliinae, Simuliidae). Bull Amer Mus Nat Hist 151 (art. 2): $129-200$ 
